China Perspectives

65 | may - june 2006

Varia

\title{
Interviews with Yang Jiang
}

\section{Liu Meizhu}

\section{OpenEdition}

Journals

Édition électronique

URL : http://journals.openedition.org/chinaperspectives/636

DOI : 10.4000/chinaperspectives. 636

ISSN : 1996-4617

\section{Éditeur}

Centre d'étude français sur la Chine contemporaine

\section{Édition imprimée}

Date de publication : 1 juin 2006

ISSN : 2070-3449

\section{Référence électronique}

Liu Meizhu, «Interviews with Yang Jiang », China Perspectives [En ligne], 65 | may - june 2006, mis en ligne le 01 juin 2009, consulté le 28 octobre 2019. URL : http://journals.openedition.org/ chinaperspectives/636; DOI : 10.4000/chinaperspectives.636

Ce document a été généré automatiquement le 28 octobre 2019

(c) All rights reserved 


\section{Interviews with Yang Jiang}

\section{Liu Meizhu}

“Adversity makes you strong” (written on January 1st 2005)

1 Apart from Recovering Footsteps, The Shadow and The Art of Listening, were your other sanwen [prose texts that are not fictional, and not really essays] published at the time, in the 1930s and 1940s?

2 Yang Jiang - All my sanwen were first published individually, and then brought together in collections. The publisher Renmin wenxue has just brought out a Collected Works of Yang Jiang in eight volumes: the first four are devoted to my own works, and the other four to my translations. There is also a preface and some biographical information, which I wrote, and to which you can refer.

3 Li Jianwu [(1906-1982), a well-known literary critic, playwright and translator, who made available to Chinese readers the works of Flaubert, Stendhal and Molière], in an article written in 1944, referred to your comedy Truth Becomes Falsehood. Do you know where this article was published?

4 If I remember correctly Li Jianwu said that Truth Becomes Falsehood would "be a milestone in the history of comedy". It was probably in some sort of publicity, but I don't remember in which article it appeared.

5 The script of your third comedy, Having Fun In This World, seems to have been lost. Did you ever find it again?

6 It was the famous Yao Ke who directed it, but the script was unsatisfactory, so I destroyed it myself. I did not want it to survive.

7 What is your favourite among all your works?

8 I do not have a favourite.

9 Is there anything that you regret in your life?

10 Not having been able to study literature at Qinghua University, and having instead studied politics at Dongwu University.

11 Do you have any religious beliefs? 
I do not practise any religion, but I am not wholly an atheist. I believe in God and in Man, in his ability to do good.

I have the impression that in your work you are mainly concerned with Man and human morality, rather than criticising society, politics or the system. Is that so?

Yes.

5 You do not take delight in heroism, or in idealism, but at the same time you believe in the power of Man. And that power does not lie in convincing others, or in changing the world, but rather in adapting oneself to people and to situations (in particular unfavourable situations), in order to live better and to serve society as best one can. Am I right?

Yes. But the most important thing is not to adapt to the demands of society, but to excel oneself. Difficulties are revelatory [of one's true character]; "adversity" makes one strong.

In at least two of your essays, one comes across the expression "Western humanism". What in your opinion most distinguishes "Western humanism" from "Eastern humanism"?

They are identical.

9 It is said that the writers whose style is closest to yours are, among foreign writers, Jane Austen, and among Chinese writers, Ling Shuhua. Do you agree?

No.

You have mastered several foreign languages and you have extensive knowledge of foreign literatures and cultures. But despite this, you seem to have remained a pure traditional Chinese scholar, of whom very few are to be found nowadays. Am I right?

Yes, that's true.

Your philosophy of life is closer to that of the traditional scholars, like Chen Yinge, Lin Yutangand of course Qian Zhongshu-, and even to that of the scholars of ancient times: Su Dongpo and Tao Yuanming.

24 I love Su Dongpo, he is the most humane of all. I also admire Tao Yuanming for his great strength of spirit. I am not sufficiently familiar with the other scholars you mention.

25 We know that it was a private tutor, and then his uncle, who taught classical Chinese to Qian Zhongshu. Where did you study the classic texts, and in what circumstances?

I studied them by myself, which is why I do not feel very qualified on the subject.

In We Three, you recall that you were registered at the Sorbonne in the 1930s. Do you remember what was to be the subject of your thesis?

The French novel.

If at some point in your life, you had had to choose between your work and your family, would you have sacrificed everything to follow your career?

30 Fortunately, I was born into a harmonious household, and later the little family that I formed with my husband and daughter was a happy one. I never had any thought of abandoning it. I have never had to choose between my professional activities and my family life.

31 What do you see as the meaning of existence?

To try to be someone of value, not to waste one's life. 
What kind of people do you like best?

All people, whatever their age or social position. All people are kind.

And which do you hate the most?

Those who hate me. I hate them too.

"My way of living is also a product of Confucianism" (written on July 28th 2005)

I am wondering at present about the things which have influenced your personality: your innate intelligence, the upbringing your parents gave you, the education you received at school, your knowledge of Chinese and Western cultures (in particular those classical), the influence that your teachers and friends have had on you, as well as Qian Zhongshu, and also the experiences you have lived through. My conclusion is that the most important thing has been your innate intelligence.

Yang Jiang - I do not think that I was a child prodigy, I was just a little better than average. I was lucky enough to be born into a family that did not consider men to be superior to women. As a child I was educated by my father with great care. What he wanted, even if he never expressed it in these words, was for me to know how to think independently and to show iron determination.

Several well-known personalities in modern Chinese history, who also have extensive knowledge of Western and Chinese cultures, have said that the time they spent living abroad allowed them better to appreciate classical Chinese culture. Do you share this feeling?

My studies abroad were only a continuation of the studies I had done in China. In the suitcases we took with us [she and Qian Zhongshu], there were above all the Chinese classics. We read them conscientiously every day, without exception. When I was in secondary school, the school accorded more importance to mathematics, physics or English classes, and our Chinese teacher was often badly treated by the pupils. My grounding in classical Chinese is not very solid, and I have always, right up to this day, sought to improve it. I find that those who have no knowledge of any foreign language are often extremists, either on the far Left or ultra conservative.

41 You say that you believe in God. When did you begin to believe, and in what circumstances? Is this in some way related to the Qiming school, which you attended, and which was run by foreign missionaries?

42 My primary school was run by Catholics, and my university by Christians. But the schools had no influence on my beliefs, and I am not a believer [in the strict sense of the word]. My faith has not been influenced by anybody, it arose and strengthened itself by experience, through reading and rereading, and by long and mature reflection.

43 In the thesis I am writing about you, I describe you as a traditional Chinese intellectual, steeped in humanism. This is because I see that in your individual way of being you behave like a Confucian, and like a Taoist where society is concerned. And you have a marked propensity to advocate humanism. Do you agree?

44 I almost agree with you. Except that I think my way of living, as well my individual behaviour is Confucian. The book I most admire is the Analects of Confucius. Confucius, to me, is the greatest of the humanists.

Translated from the French original by Michael Black 
Works of Yang Jiang translated into English:

- Lost in the Crowd: A Cultural Revolution Memoir, translated by Geremie Barme, Melbourne, McPhee Gribble, 1989.

- "The Art of Listening”, “The Cloak of Invisibility”, in David Pollard (ed.), The Chinese Essay, Hong Kong, A Renditions Book, 1992 (reed.: New York, Columbia University Press, 2000)

- Forging the Truth, in Amy D. Dooling (ed.), Writing Women in Modern China: The Revolutionary Years, 1936-1976, New York, Columbia University Press, 2005.

\section{RÉSUMÉS}

Yang Jiang was born, under her real name of Yang Jikang, in 1911. She is the author of a novel, several plays, and a large number of sanwen. Her first writing dates back to 1933, and her latest work, Women sa (We Three), in which she recalls family memories, appeared in July 2003, and has been highly successful, with 180,000 copies sold within two months. However, for thirty years, from 1949 to 1981, for obvious reasons, Yang Jiang preferred to devote herself entirely to teaching, research-she is also an expert on Chinese and foreign literature-, and translation: she is the translator, most notably, of the Chinese version of Don Quixote. She is now devoting herself to the publication of the work of her husband, the scholar Qian Zhongshu (1910-1998). In France she is best known for her narratives of the Cultural Revolution, published by Christian Bourgois.

The two interviews that follow were carried out in 2005. Yang Jiang gave written answers to the questions I had sent her, which explains the slightly abrupt nature of our exchanges, given that it was not possible for me, by the nature of the interviews, to respond spontaneously to her words. If we seem to jump from one subject to another, it is because I had asked her to clarify certain details that I planned to use in my research into her work (« La Figure de l'intellectuel chez Yang Jiang " ["The Intellectual in The Work of Yang Jiang"], which became my doctoral thesis in Chinese Studies, under the direction of Isabelle Rabut, Inalco, Paris, December 2005, 404 pp.). Yet, to me, these words of Yang Jiang are of interest just as they are, since she uses words so sparingly and generally refuses to do interviews. In any case, and I am grateful to her for this, she only allowed these words to be published precisely because she had written them herself. 